\title{
Developing strategic international human resource capabilities in Sub-Saharan Africa
}

\author{
Dr. Ellis L.C. Osabutey \\ International Management and Innovation Department \\ Middlesex University Business School \\ The Burroughs, London, NW4 4BT \\ Email: e.osabutey@mdx.ac.uk \\ Tel: +44(0)2084115282 \\ Dr. Richard B. Nyuur \\ Newcastle Business School \\ Northumbria University \\ Newcastle, NE1 8ST, UK. \\ Email: richard.nyuur@northumbria.ac.uk \\ Tel: + 44 (0) 1912273336 \\ Prof Yaw A. Debrah \\ School of Business and Economics, \\ Haldane Building, \\ Swansea University \\ Swansea, SA2 8PP, UK \\ Email: y.a.debrah@swansea.ac.uk \\ Tel: +44 (0) 1792295763
}




\section{Developing strategic international human resource capabilities in Sub-Saharan Africa}

\section{Introduction}

Liberalization, deregulation, globalisation and technological developments have made the global business environment more fluid in terms of changes, innovations, new product developments, emerging markets opportunities, challenges and competitive pressures (Calkins \& Berman, 2004). Technology has connected the world, increased accessibility, visibility and transparency and business activities have become international and global (Ulrich, Brockbank, Johnson \& Younger, 2009; Shen, 2011). Employees are increasingly from diverse backgrounds, with constantly changing expectations as they gain more experience, skills and education.

In many contexts, organisations competitive emphasis have morphed from market oriented to being more resourced oriented (SaáPérez \& García-Falcón, 2002). This is based on the erosion of the mind-set that competitive advantage in these contexts is gained and sustained primarily from state ownership and support, or entry into key geographical or product markets. The eroding of regulatory protection from both domestic and foreign competition, have forced firms to reorient their competitive strategies to developing key organisational resources and capabilities.

As a result, organisations now find themselves under heightened pressure to tap into their internal resources and align them effective- 
ly with the dynamics within the external environment in order to make sense of the driving forces and trends and strategically adapt to ensure survival and achieve competitive advantage (Caligiuri, 2006). Moreover, internal complexity of an organisation has to mirror its external environment through innovation and coordination of resources (Dickmann \& Müller-Camen, 2006). This is in line with the resource based-view and recognition among strategic management researchers and practitioners that sustained competitive advantage emanates more from a firm's bundle of tangible and intangible internal resources (Wernerfelt, 1984; Barney, 1991; Grant, 1991).

Scholars of strategic human resource management view people as one of the vital internal resources that can contribute to a firm's competitive advantage (Adeleye, 2011). The established view in this body of scholarship is that people constitute the most important asset of a firm. The effective deployment human resource can offer firms a distinctive and non-imitable competitive advantage (Chew and Horwitz, 2004; Ghebregiorgis and Karsten, 2007; Guest, 2002). Arguably, while technology, plant and equipment are some of the strategic organisational resources, the human resource enables organisations to combine these resources effectively and add value in their productive process. An increasing body of scholarly work on strategic human resource management predominantly underscores this view. Moreover these studies examine the conditions under which human resource systems or practices would generate a sustained competitive advantage (Wright, McMahan \& McWilliams, 1994; Lado \& Wilson, 1994). 
Drawing on the resource-based view, the human capital theory, and the resource - capability theory, these studies provide that when this strategic human resource is effectively deployed within human resource (HR) systems or practices, it can lead to the development and sustenance of competitive advantage (Gurbuz \& Mert, 2011; Kamoche, 1996). For instance, Lado and Wilson (1994) provided a conceptual framework with propositions of how HR systems can facilitate the development and destruction of organisational competencies. Furthermore, the potential of an HR system to facilitate or inhibit the development and utilization of organizational capabilities has also examined and acknowledged (Lado and Wilson, 1994; SaáPérez \& García-Falcón, 2002). The findings in these studies have to a degree entrenched in management theory and practice that human resource is a source for developing capabilities and sustainable competitive advantage.

Notwithstanding, there is ambiguity as to how human resource is different from capabilities and what kind of organisational capabilities are developed from the deployment of human resource. This leaves us less knowledgeable as to what human resources capabilities are and exactly how they contribute to a firm's competitive advantage. Secondly, the complexity of the international business environment requires firms to develop unique, rare, un-substitutable and inimitable capabilities as solutions to enable them gain and maintain competitive advantage. Yet, studies on firms' international human resources as strategic within the context of international activities of the firm are comparatively low with predominance of these studies 
based on developed and Western countries and cultures (Kamoche, 1996b).

In this chapter, we seek to capture and bring together empirical and conceptual scholarly work on the types of organisational capabilities that can be developed mainly from the deployment of human resources both in the national and international business environment. Furthermore, we discuss the potential moderating effects of the HR systems and practices on the deployment of firm's human resource in the development of organisational capabilities. In other words the study maps out those capabilities that are largely dependent on firms' human resources in domestic and in the international environments. Admittedly, HR is not the only organisational resource that can facilitate the development of organisational capabilities, but focusing on only the HR related capabilities will refine our understanding of how HR should be deployed and how it contributes to gaining and sustaining competitive advantage.

Empirical excerpts on this issue are taken form organisations in the sub-Sahara African context. Africa is a multicultural, multilingual, multi-ethnic and multi-regional in nature with multi-historical experiences in many of its countries. The continent's diversity spans its 56 countries in terms of geographical, cultural, historical, economic and socio-political contexts. It is home to indigenous Africans, Arabs, Indians and all nationalities in the world from the east, west, central and the south, and has over 2,000 languages and ethnic groups (Kamoche, 2011; Adeleye, 2011). Thus, the continent's diversity reflects its colonisation legacy; the level of social, political 
and economic development; the state of institutions; the cultural and ethnic groupings; and religious affiliations (Adeleye, 2011).

The continent therefore exemplifies the global business environment in terms of the vast and widespread diversity. This diversity poses a complex challenge to firms as to how to effectively deploy their diverse human resource strategically across different cultural and regulatory environments in order to gain and sustain competitive advantage. Moreover, the diversity and complexity impact the kind of HR practices employed by organizations. Existing literature has not improved our understanding adequately on perspectives that relate to human resource capabilities in sub-Saharan Africa (SSA). Using the views of managers in a number of organisations operating in Africa, we present some of the HR capabilities developed in these organisations from the deployment of their human resource.

\section{Human resources and capabilities}

The main tenet of the resource based-view is that organisations' internal resources and capabilities constitute the driving determinants of a firm's strategy and competitive success (Wernerfelt, 1984; Mahoney, 1995). However, the question not always clearly answered is what these resources and capabilities are. Some scholars have referred to resources as the tangible and intangible stock of factors available, owned and controlled by the firm (Amit and Schoemaker, 1993). Grant (1991) also suggests that resources include all those inputs an organisation uses in its production process. Amit and Schoemaker (1993:35) further point out that "Resources are con- 
verted into final products or services by using a wide range of the firm's other assets and bonding mechanisms, such as technology, management information systems, incentive systems, trust between management and labour and so on". Barney (1991) thus categorized these resources into physical, human and organisational resources. This categorization reinforces the centrality of people in organisations as a source of competitive success.

Kamoche (1996a) therefore clarifies that the human resource element includes the accumulated stock of knowledge, skills, and abilities that individuals possess within the organisation which the firm has built up over time into an identifiable expertise. In this paper, we define human resource in line with other scholars as the pool of human capital under the firm's control in a direct employment relationship which confers uniqueness on each firm in their effort to gain and sustain competitive advantage (Wright, McMahan and McWilliams, 1994; Kamoche, 1996a).

Scholars in this area acknowledge that the human resource satisfies the four conditions necessary to achieve sustainable competitive advantage (Tyson, 1997; Gurbuz \& Mert, 2011). Specifically, human resource meets the criteria of a valuable, rare, inimitable and non-substitutable resource and thus constitutes a source of competitive advantage (Wright et al., 1994). The traditional sources of competitive advantage such as natural resources, technology, economies of scale, are increasingly easy to imitate in the contemporary business environment although they still create value (Saá-Pérez \& García-Falcón, 2002). Furthermore, Khatri (2000) argues that competi- 
tors can easily duplicate competitive advantage obtained through better technology and products, but acknowledged the difficulty of a firm's ability to duplicate competitive advantage gained through better management of people.

The difficulty of replicating people's knowledge, abilities, experience and behaviour, coupled with the high transaction cost of people acquisition or mobility contribute to the inimitability of human resource (Saá-Pérez \& García-Falcón, 2002). Also, personnel who are able to create value in one company may not be able to strategically adapt and create value in others (Wright et al., 1994). Moreover, the heterogeneity in the labour market makes it difficult to find highly motivated and guaranteed high level performance people in all organisations, underscoring the view that human resource is rare.

Notwithstanding, some strategic human resource scholars use the terms (resources and capabilities) interchangeably (Hall, 1993; Prahalad and Hamel, 1990). Ray, Barney and Muhanna (2004) for instance referred to both resources and capabilities as the tangible and intangible assets of firms employed to develop and implement their strategies. Some labelled resources and capabilities together as distinctive competence (Fiol, 1991), firm-specific competencies (Pavitt, 1991), and core competence (Prahalad \& Hamel, 1990). However, Amit and Schoemaker (1993) distinguished between the two by suggesting that capabilities include the ability of a firm to effectively deploy its resources, while Grant (1991) simply refers to capabilities as what the firm can do with the resources. Capabilities may also 
arise from a firm's network ties with its internal and external stakeholders such as employees, suppliers and customers.

From the forgoing, it can be gleaned that human resource capabilities are classified as processes, practices, systems, and outcomes of the processes and systems. The human resource capability-based view is thus seen to be concerned with actions, processes and related behavioural efforts to attain a competitive advantage (Kamoche, 1996a). These capabilities are firm specific tangible or intangible information-based processes, practices or systems that are developed over time through complex interactions among the firm's resources and exchanging of information within its human capital (Amit and Schoemaker, 1993). Saá-Pérez \& García-Falcón (2002) further emphasise that capabilities are developed from the deployment of human resources and capabilities. Kamoche (1996a) also reveals that HR capabilities are difficult to identify but depend on the firm's capacity to secure, nurture, retain and deploy human resources through HR practices and policies.

Two studies pointed out four main specific organisational capabilities that firms can develop from the deployment of their human and other tangible and intangible resources. These include managerial capabilities, input-based capabilities, transformational capabilities, and output-based capabilities (Lado \& Wilson, 1994; Saá-Pérez, \& García-Falcón, 2002). Accordingly, the managerial capabilities refer to the degree of commitment and involvement of the human resource, and the relevance of human resource issues in strategic decisions making in the organisation (Lado \& Wilson, 1994). The input- 
based capabilities include training, incentives and motivation of firm specific human capital, while encouraging creative and innovative ability in the employees constitute the transformational capabilities (Saá-Pérez, \& García-Falcón, 2002).

Table 1: Functional and organisational capabilities from human resource deployment

\begin{tabular}{|c|c|c|}
\hline Resource & $\begin{array}{l}\text { Functional Area capa- } \\
\text { bilities }\end{array}$ & $\begin{array}{l}\text { Resulting overall organisation- } \\
\text { al capabilities }\end{array}$ \\
\hline Human Resource & $\begin{array}{l}\text { - Purchasing capabili- } \\
\text { ties } \\
\text { - Retailing and Distri- } \\
\text { bution capabilities }\end{array}$ & $\begin{array}{l}\text { Output-based capabilities } \\
\text { Good relationship with cli- } \\
\text { ents, suppliers, public insti- } \\
\text { tutions, etc. } \\
\text { - Good corporate image }\end{array}$ \\
\hline \multirow[t]{3}{*}{$\begin{array}{l}\text { Human Resource } \\
\text { systems } \\
\text { Human resource } \\
\text { practices }\end{array}$} & $\begin{array}{l}\text { Effective Branding } \\
\text { capabilities } \\
\text { - } \quad \begin{array}{l}\text { Research and De- } \\
\text { velopment capabili- } \\
\text { ties }\end{array}\end{array}$ & $\begin{array}{l}\text { Managerial capabilities } \\
\text { - } \begin{array}{l}\text { Degree of commitment } \\
\text { and involvement of per- } \\
\text { sonnel }\end{array} \\
\text { - Importance of HR aspects } \\
\text { in strategic decisions }\end{array}$ \\
\hline & $\begin{array}{l}\text { - Net Working capa- } \\
\text { bilities } \\
\text { - Marketing, Sales, } \\
\text { Promotion and Cus- } \\
\text { tomer Relations }\end{array}$ & $\begin{array}{l}\text { Input-based capabilities } \\
\text { - Training of firm-specific } \\
\text { human capital } \\
\text { - Incentives and motivation } \\
\text { of specific human capital }\end{array}$ \\
\hline & $\begin{array}{l}\text { Corporate culture } \\
\text { and accountability } \\
\text { capabilities }\end{array}$ & $\begin{array}{ll}\text { Transformational capabili- } \\
\text { ties } & \\
\text { - } & \begin{array}{l}\text { Encouraging creative and } \\
\text { innovative ability in the } \\
\text { employees }\end{array}\end{array}$ \\
\hline
\end{tabular}

Source: Saá-Pérez \& García-Falcón (2002) and views from managers.

Finally, good corporate image and strong relationship with relevant stakeholders such as clients, customers, suppliers and public institu- 
tions constitute the output-based capabilities (Lado \& Wilson, 1994; Saá-Pérez, \& García-Falcón, 2002). Views from managers in organisations in SSA further reveal that the deployment of human resources also contributes to the development of capabilities in functional areas of an organisation. See Figure 1 above.

\section{International HR capabilities}

The organisation life cycle (OLC) approach suggests that global firms usually go through four main stages: domestic, international and global (Milliman et al., 1991). At each stage competition increases and requires specific capabilities to succeed. Moreover, as the firm moves from one stage to the next, the complexity increases requiring enhanced strategic capabilities to withstand the competitive pressures. Arguably, different human resource capabilities may be required at each stage. Developing human resource capabilities in international or global companies to address some of the complex issues in the diverse global business context is however a challenge (Calkins and Berman, 2004; Singer, 2002). The international human resource management strategy has to be matched with the prevailing international business imperatives as defined by the product-market realities, cultural and institutional requirements and diversity issue.

Notwithstanding the international human resource management scholarship focuses mainly on expatriates career management and the complexities of managing across borders (Kamoche, 1996b). The scope for assessing and capturing the strategic value and capabilities developed from the deployment of diverse human resource 
has not been adequately discussed in the literature. However, one of the most critical human resource capabilities for multinational or global companies is the development of global leadership skills. Global leaders, defined as executives who are in jobs with some international scope (Spreitzer, McCAll, and Mahoney, 1997), need to develop and implement strategic goals that create sustainable value while responding to key stakeholders (Thompson, 2010).

The challenge for managers in the twenty-first century demands the overriding requirement that they are capable of leading and operating in an increasingly complex, interdependent and dynamic global business environment. The role necessitates leadership skills that allow managers to analyse each business environment critically to develop and implement appropriate strategies and operating styles (Deresky 2014). Viceri and Fulmer (1997) contend that strategic leadership development is a critical ingredient required for the strengthening of organisation's strategic competitive position. Caligiuri (2006) further underscore that successful global leaders are a source of competitive advantage. The effectiveness of multinational enterprises (MNEs) depends on the development of cross-cultural competences (Stroh and Caligiuri, 1998; Deresky, 2014). Contingency theories of leadership also argue that effective leadership is context specific (Vroom, 1993; Hersey, Blanchard and Johnson, 1996). In the next section we examine global leadership in the context of SSA and challenges of developing this human resource capability. 


\section{Culture and Institutional Influences on Global Leadership}

Jackson (2011) observed that within the context of international management and organisation studies, particularly within developing regions such as SSA, there is the need to clarify what is considered 'cultural' and 'institutional'. Institutional theory suggests that institutions consist of formal and informal constraints. The formal constraints include laws, contracts and constitutions whilst the informal constraints include certain behaviours, norms, conventions and selfimposed codes of conduct. Arguably, the informal constraints are 'cultural' in nature and these vary across geographical locations. These constraints and their enforcement characteristics regulate economic activities (North, 1990; Scott, 1995). Consequently, institutions are fundamental in the political, legal and socio-cultural environment and determine levels of transparency and corruption. Institutions establish the rules of engagement in the economic and operational activities of firms (North, 1990). Institutions can therefore be capable of easing and/or restraining the performance of firms (Malik \& Kotabe, 2009; Ricart et al., 2004).

This understanding of the institutional framework agrees with Sorge (2004) who believes that the 'culturist' and 'institutionalists' approaches should be complementary in international management. In the global context, therefore, global leaders must develop the skills that enable them to deal with local as well as global cultural and institutional dimensions in response to the increasingly diverse and complex diverse business environment. The need to incorporate varying business practices and expectations of multiple and yet 
unique stakeholders, with particular emphasis on local managers, in strategy formulation and implementation is crucial for success. HR is expected to fashion out what best practices in areas such as recruitment and selection, human resource planning, training and development, performance appraisal and industrial relations would help achieve strategic goals. These HR functions are affected by the institutional and cultural factors. Some of these are discussed in Table 1.

\section{International HRM in Africa}

A vital component of implementing global strategy is international human resource management (IHRM). Mendenhall, Black, Jensen, and Gregerson (2003) observed that the major challenges that the human resource (HR) function faces in the globalised business environment include; enhancing global business strategy, aligning HR issues with business strategy, designing and leading change, building global corporate cultures, and staffing organisations with global leaders. The IHRM function covers recruitment and selection, preparation and training, and setting up appropriate pay and remuneration and performance management programmes. Since it is not practicable to harmonise IHRM practices, Deresky (2014) suggested that international managers need to deal with complex local government laws and regulations, varying cultural norms and practices, as well as the local business practices. The dynamics of the HR function becomes compounded in a SSA context where cultural and institution- 
al dimensions play an active role. Table 1 introduces elements of these in the SSA context. The information in Table 1 is based on interviews held in July 2014. Respondents are made up of 4 HRM practitioners in 4 different MNEs, 2 local HR Consultants and 1 Trade union representative in Ghana.

Table 2: Institutional and Cultural Influences on HRM practices

\begin{tabular}{|c|c|c|}
\hline $\begin{array}{l}\text { Local Laws } \\
\text { and Practices }\end{array}$ & $\begin{array}{l}\text { Effect of Culture on } \\
\text { IHRM Function }\end{array}$ & $\begin{array}{l}\text { How to reduce the im- } \\
\text { pact on the organisation }\end{array}$ \\
\hline & Recruitment \& Selection & \\
\hline $\begin{array}{l}\text { Qualifications } \\
\text { vs Nepotism }\end{array}$ & $\begin{array}{l}\text { Although qualifications are } \\
\text { required the selection process is } \\
\text { mired by predominant nepotism } \\
\text { and corruptive practices be- } \\
\text { cause HRM roles are often un- } \\
\text { dertaken my local employees. }\end{array}$ & $\begin{array}{l}\text { This means that the best peo- } \\
\text { ple may not be hired. Headquar- } \\
\text { ters (HQ) HR could have some } \\
\text { oversight into local hiring prac- } \\
\text { tices. Expatriates not from the } \\
\text { host country can also be involved } \\
\text { in the process. This could serve } \\
\text { as a deterrent to potential deliber- } \\
\text { ate recruitment and selection ex- } \\
\text { ploitation and malpractices. }\end{array}$ \\
\hline $\begin{array}{l}\text { Equal Opportu- } \\
\text { nities vs Women's } \\
\text { Roles }\end{array}$ & $\begin{array}{l}\text { Masculinity predominates at } \\
\text { the higher levels. Hiring wom- } \\
\text { en, particularly at the lower } \\
\text { level, can often be influenced } \\
\text { by unfair and unethical practic- } \\
\text { es. Hiring practices can also be } \\
\text { influenced by tribal or political } \\
\text { influences. Overt hiring from a } \\
\text { particular tribe or kinsmen is } \\
\text { possible. Masculinity and nepo- }\end{array}$ & $\begin{array}{l}\text { The influence of masculinity } \\
\text { and nepotism would adversely af- } \\
\text { fect the development of skilled } \\
\text { workforce because capability and } \\
\text { performance does not adequately } \\
\text { influence recruitment, human re- } \\
\text { source and career development. } \\
\text { HQ oversight and expatriate in- } \\
\text { volvement in recruitment and } \\
\text { performance management be- }\end{array}$ \\
\hline
\end{tabular}




\begin{tabular}{|c|c|c|}
\hline & $\begin{array}{l}\text { tism also influence career de- } \\
\text { velopment and promotion }\end{array}$ & comes vital \\
\hline \multirow[t]{2}{*}{$\begin{array}{l}\text { Laws with re- } \\
\text { spect to hiring local } \\
\text { employees }\end{array}$} & $\begin{array}{l}\text { Where such laws exist, HR } \\
\text { would need to prove that requi- } \\
\text { site skills are not available lo- } \\
\text { cally to recruit foreign workers }\end{array}$ & $\begin{array}{l}\text { Such laws are hardly enforced } \\
\text { and pervading corruption means } \\
\text { that foreign firms can flout such } \\
\text { laws. This means that, where it is } \\
\text { in the interest of firms to hire lo- } \\
\text { cals, they would always do so. }\end{array}$ \\
\hline & $\begin{array}{l}\text { Training \& Development } \\
\text { (T\&D) }\end{array}$ & \\
\hline $\begin{array}{cr}\text { Skills levels, } \\
\text { certification } \\
\text { quirements }\end{array}$ & $\begin{array}{l}\text { A disconnect between what } \\
\text { organisations need and what } \\
\text { the education and training insti- } \\
\text { tutions produce exists across all } \\
\text { levels of the educational sys- } \\
\text { tems. The disconnect means } \\
\text { that the human capital with lo- } \\
\text { cal knowledge together with an } \\
\text { innovative and global mindset } \\
\text { is often missing. Certification } \\
\text { outside formal education is of- } \\
\text { ten not adequately reliable }\end{array}$ & $\begin{array}{l}\text { Most education and training } \\
\text { institutions produce cost effective } \\
\text { human capital according to de- } \\
\text { mand from potential students } \\
\text { with no corresponding match to } \\
\text { the needs of firms and the local } \\
\text { economy. HR function may use } \\
\text { internships and other collabora- } \\
\text { tive arrangements to help develop } \\
\text { requisite human capital }\end{array}$ \\
\hline $\begin{array}{l}\text { HQ vs Local } \\
\text { Training }\end{array}$ & $\begin{array}{l}\text { Disconnect discussed above } \\
\text { means HQ and their subsidiar- } \\
\text { ies should be actively be in- } \\
\text { volved in the training and de- } \\
\text { velopment of human resource. }\end{array}$ & $\begin{array}{l}\text { HQ and subsidiary support } \\
\text { and deliberate policies need to } \\
\text { continuously identify and devel- } \\
\text { op host country employees who } \\
\text { have both local and global } \\
\text { knowledge as part of the man- } \\
\text { agement cadre. Most foreign } \\
\text { firms also poach good candidates } \\
\text { from local or other foreign firms } \\
\text { with better conditions of service. }\end{array}$ \\
\hline $\begin{array}{c}\text { Education vs } \\
\text { Apprenticeship }\end{array}$ & $\begin{array}{l}\text { The HR function would } \\
\text { need to support curriculum de- }\end{array}$ & $\begin{array}{l}\text { HR needs to identify good } \\
\text { candidates during internship or }\end{array}$ \\
\hline
\end{tabular}




\begin{tabular}{|c|c|c|}
\hline & $\begin{array}{l}\text { velopment and internship pro- } \\
\text { grammes in order to identify } \\
\text { the right talent }\end{array}$ & $\begin{array}{l}\text { collaborative programmes to en- } \\
\text { sure that key skills required are } \\
\text { passed on prior to employment. }\end{array}$ \\
\hline \multirow[t]{2}{*}{$\begin{array}{l}\text { Government } \\
\text { pressure on firms to } \\
\text { offer employee } \\
\text { training }\end{array}$} & $\begin{array}{l}\text { There hardly exist such } \\
\text { pressures. Firms use their ini- } \\
\text { tiative if the investment in } \\
\text { training can improve their per- } \\
\text { formance. }\end{array}$ & $\begin{array}{l}\text { Generally firms that invest in } \\
\text { training and development would } \\
\text { need HR to design systems that } \\
\text { can ensure employee retension. }\end{array}$ \\
\hline & Performance Management & \\
\hline \multirow[t]{2}{*}{$\begin{array}{l}\text { Achievement vs } \\
\text { Connection }\end{array}$} & $\begin{array}{l}\text { Local HRM practitioners } \\
\text { are often influenced by nepo- } \\
\text { tism. Political influence is more } \\
\text { prevalent in the public sector } \\
\text { than private sector. }\end{array}$ & $\begin{array}{l}\text { Source of power/status im- } \\
\text { portant and here again HQ and } \\
\text { expatriate oversight and in- } \\
\text { volvement can sanitise the pro- } \\
\text { cess. }\end{array}$ \\
\hline & Industrial Relations & \\
\hline Trade Unions & $\begin{array}{l}\text { Trade unions have more ef- } \\
\text { fects on public sector employ- } \\
\text { ees than private sector employ- } \\
\text { ees. Most Multinationals, with } \\
\text { the exception of those of Chi- } \\
\text { nese origin, already pay well } \\
\text { above the minimum wage. Un- } \\
\text { ions in most MNEs usually } \\
\text { have good relationships with } \\
\text { management. Chinese firms do } \\
\text { not encourage unionisation be- } \\
\text { cause the purpose of trade un- } \\
\text { ions varies across cultures. }\end{array}$ & $\begin{array}{l}\text { HRM functions in the majori- } \\
\text { ty MNEs, particularly subsidiar- } \\
\text { ies of western firms from devel- } \\
\text { oped countries, often serve as } \\
\text { benchmarks for other firms. Chi- } \\
\text { nese firms may need to also learn } \\
\text { from western MNEs in this re- } \\
\text { gard. }\end{array}$ \\
\hline $\begin{array}{l}\text { The Power and } \\
\text { Structure of Unions }\end{array}$ & $\begin{array}{l}\text { Unions are often effective } \\
\text { with respect to collective bar- } \\
\text { gaining in the public sector. } \\
\text { Most private sector local firm } \\
\text { employees do not also form un- } \\
\text { ions because being employed }\end{array}$ & $\begin{array}{l}\text { The HRM function could pub- } \\
\text { licise good practice as a social re- } \\
\text { sponsibility that could encourage } \\
\text { good practice across the work- } \\
\text { forces in the host country. This } \\
\text { could also make them the em- }\end{array}$ \\
\hline
\end{tabular}




\begin{tabular}{|l|l|l|}
\hline & $\begin{array}{l}\text { can sometimes be viewed as a } \\
\text { privilege }\end{array}$ & ployer of choice \\
\hline
\end{tabular}

Source: Constructed from authors' field notes in a related study in 2014

Some of the findings in Table 1 emphasise the diversity of HRM theory and practice and how culture and institutional issues play a role in highly complex and variable societies (Jackson, 2004; Kamoche, Debra, Howitz \& Muuka, 2004). It also gives an indication about the way the HR function needs to adapt to find ways of reducing possible negative impacts on firm performance. It is also becoming evident that HR practice in Africa may need to incorporate needs to go beyond home country practices to explore various forms of hybridisation of home and host country practices, particularly in the African context (Azolukwam \& Perkins, 2009; Jackson, Amaeshi \& Yavuz, 2008).

The nature of product or service together with the primary strategic orientation and stage of internationalisation determine the staffing modes. Most authors have referred to ethnocentric, polycentric, regiocentric and global approaches. Whilst this is important the approaches taken by MNEs also depend on the availability of the required human capital. The pertinent questions relates to where the organisation sees the benefits of recruiting locals but are faced with the absence of the quantity, quality and variety of skills. The issues faced by most multinationals relate more to the skills gaps and the choice between building local capacity and using expatriates from 
home or third countries. Consequently, Figure 1 suggests that HRM practice in Africa must operate, as far as possible and practicable, within the context of institutional and cultural frameworks that are compatible with both local and global frameworks.

Having one inflexible perspective which is purely based on home country policies and practices on one hand or adopting unadulterated host country perspectives could be counterproductive and inimical to firm performance. The cross fertilisation of home and host country practices could enhance learning for both the parent and subsidiary with the potential of transferring similar practices to similar environments. It was noted by Gomes, Angwin, Peter and Mellahi (2012) that HRM issues need to attach enormous significance to regional differences in culture. What is paramount here is that HRM policies and practices should at least be molded to suit context, with the possibility that any innovations that accrue are likely to impact on the wider practice in the host country (Wood, Mazouz, Yin, and Cheah, 2014). More importantly, lessons learnt can be extended into markets with similar cultural and institutional environments.

\section{Figure 1: HRM Practice and Institutional and Cultural Factors}

\begin{tabular}{|c|c|c|}
\hline HRM Practice & $\begin{array}{c}\text { Institutional and } \\
\text { Recruitment and Selection } \\
\text { Training and Development } \\
\text { Performance Management } \\
\text { Industrial Relations }\end{array}$ & Cultural Factors \\
Home Country and Host In- \\
stitutional and Cultural Factors \\
International Best Practice
\end{tabular}




\section{Skills Gaps and Capacity Development in Africa}

The dearth of requisite talent in a globalised business world has become one of the principal HR concerns for MNEs (Capelli, 2008). Human capital, with the skillset to incorporate global perspectives and integration with local adaptation, in an environment of continuous international learning and innovation is an urgent requirement (Kang, Morris, and Snell, 2007; Lepak and Snell, 1999). Jackson (2004) highlights how Western management styles with respect to how MNEs manage their human resources can sometimes contrast or contradict African managerial values and practices. Asiedu (2004) observed that MNEs operating in Africa often encountered challenges that encompass lack of talent (quality, variety and quantity), effective work practices, institutional and cultural differences. A vibrant HRM or IHRM is required to navigate these challenges.

One of the greatest challenges for MNEs operating in Africa is the shortage of skills and the need to develop, recruit and retain requisite skills. Mellahi and Collings (2010) suggest that one approach to developing local talent would be to tap into global knowledge and talent stock from subsidiary networks. However, it appears the existing body of knowledge has failed to evaluate the development of African talent to feed into the stock of global knowledge. Skills gaps at all levels have been a problem for many MNEs operating in Africa. The HR function needs to identify local talent to develop as global leaders whilst at the same time ensuring that the skills gaps at all 
levels are also addressed. The skills gaps require a framework that is able to match demand and supply within the local and global context. The HR function can begin to evaluate how the lower and middle level human resource can be developed and retained for the day to day running of their business. In addition, it is important that attempts are made to develop managers who can operate beyond their home country first at the regional level and then at a more global level. The challenge of achieving this has not been given adequate attention by researchers and practitioners and more attention is needed particularly in the SSA context.

\section{Conclusion}

The chapter has discussed the development of human resource capabilities and organisational human capital development from a global perspective but with SSA contextual inferences. With an acknowledgement that the existing literature on strategic HRM requires the examination of contextual human resource systems and practices, the chapter throws light on the diversity and complexity of managing in SSA. With empirical excerpts, the challenges firms in the region face with respect to HRM policies and practices are expounded. One of the issues of pertinent importance is the existing skills gaps at lower, middle and higher levels of operational and managerial activities have been considered. The nuances introduced by the complex cross-cultural and institutional arrangements require that successful HRM practice in the region requires the in-depth awareness and understanding of these issues. 
Although the empirical data used is limited, in its nature and scope, there appears to be a suggestion that some level of HQ oversight and expatriate involvement in HR policy and practice could advance the role of HR in dealing with ethical issues within organisations as well as enhance the selection and development of the human resource for superior performance. It is also worth emphasising the suggested HQ oversight and expatriate involvement should not lead to the total exclusion of host country HR practitioners whose understanding of prevailing cultural and institutional dynamics are indispensable. HR's role or involvement in the training and development of potential employees even before they are employed is an issue worth exploring. In addition, the need to invest in the development of African global management cadre for the region and beyond should be the responsibility of HR directors and managers to engender African global leadership talent.

\section{References}

Adeleye, I. (2011). Theorising human resource management in Africa: Beyond cultural relativism. African Journal of Business Management, 5(6), 2028-2039.

Amit, R., \& Schoemaker, P. J. (1993). Strategic assets and organizational rent. Strategic management journal, 14(1), 33-46.

Asiedu, E. (2004). The Determinants of Employment of Affiliates of US Multinational Enterprises in Africa. Development Policy Review, 22(4), 371-379.

Azolukwam, V.A., and Perkins, S.J. (2009). Managerial perspectives on HRM in Nigeria: Evolving Hybridisation? Cross Cultural Management: An International Journal, 16(1), 62-82. 
Barney, J. (1991). Firm resources and sustained competitive advantage. Journal of management, 17(1), 99-120.

Caligiuri, P. (2006). Developing global leaders. Human Resource Management Review, 16, 219-228.

Calkins , M. and Berman, S.L. (2004). Special Issue: Business Ethics in Global Economy. Business Ethics Quarterly 14(4), 597601.

Capelli, P. (2008). Talent on demand: Managing talent in an age of uncertainty. Boston: Harvard Business Press.

Chew, I. K., \& Horwitz, F. M. (2004). Human resource management strategies in practice: Case-study findings in multinational firms. Asia Pacific Journal of Human Resources, 42(1), 32-56.

Conner, K. R. (1991). A historical comparison of resource-based theory and five schools of thought within industrial organization economics: do we have a new theory of the firm?. Journal of management, 17(1), 121-154.

Deresky, H. (2014). International Management: Managing Across Borders and Cultures (Text and Cases) $\left(8^{\text {th }}\right.$ ed.). London: Pearson.

Dickmann, M., \& Müller-Camen, M. (2006). A typology of international human resource management strategies and processes. The International Journal of Human Resource Management, 17(4), 580-601.

Fiol, C. M. (1991). Managing culture as a competitive resource: An identity-based view of sustainable competitive advantage. Journal of management, 17(1), 191-211.

Ghebregiorgis, F. and L. Karsten (2007), 'Employee reactions to human resource management and performance in a developing country: evidence from Eritrea', Personnel Review, 36(5), $722-738$.

Gomes, E., Angwin, D., Peter, E., and Mellahi, K. (2012). HRM issues and outcomes in African mergers and acquisitions: a study of the Nigerian banking sector. The International Journal of Human Resource Management, 23(14): 2874-2900.

Grant, R. M. (1991). The resource-based theory of competitive advantage: implications for strategy formulation. California Management Review, 17, 114 - 135. 
Guest, D. (2002). Human resource management, corporate performance, and employee well-being: building the worker into HRM. The Journal of Industrial Relations, 44(3), 335-358.

Gurbuz, S., \& Mert, I. S. (2011). Impact of the strategic human resource management on organizational performance: evidence from Turkey. The International Journal of Human Resource Management, 22(8), 1803-1822.

Gurbuz, S., \& Mert, I. S. (2011). Impact of the strategic human resource management on organizational performance: evidence from Turkey. The International Journal of Human Resource Management, 22(8), 1803-1822.

Hall, R. (1993). A framework linking intangible resources and capabiliites to sustainable competitive advantage. Strategic management journal, 14(8), 607-618.

Hersey, P., Blanchard, K. and Johnson, D. (1996). Management of Organisational Behaviour ( $7^{\text {th }}$ ed.). Upper Saddle River, N.J.: Prentice Hall.

Jackson, T. (2011). From cultural values to cross-cultural interfaces: Hoftede goes to Africa. Journal of Organisational Change Management, 24(4): 532-558.

Kamoche, K. (1996a). Strategic human resource management within a resource-capability view of the firm. Journal of Management studies, 33(2), 213-233.

Kamoche, K. (1996b). The integration-differentiation puzzle: a resource-capability perspective in international human resource management. International Journal of Human Resource Management, 7(1), 230-244.

Kamoche, K. (2011), 'Contemporary developments in the management of human resources in Africa', Journal of World Business, 46(1), 1-4.

Kamoche, K., Debrah, Y.A., Horwitz, F.M., and Muuka, G.N. (eds.) (2004), Managing Human Resources in Africa. London: Routledge.

Kang, S.-C., Morris, S., \&Snell, S.A. (2007). Relational archetypes, organisational learning, value creation: Extending the human resource archetype. Academy of Management Review, 32(1): 236-256. 
Khatri, N. (2000). Managing human resource for competitive advantage: a study of companies in Singapore. The International Journal of Human Resource Management, 11(2), 336-365.

Khatri, N. (2000). Managing human resource for competitive advantage: a study of companies in Singapore. International Journal of Human Resource Management, 11(2), 336-365.

Lado \& Wilson (1994) Human resource systems and sustained competitive advantage: A competency - based perspective. Academy of Management Review, 19(4), 699 - 727.

Lepak, D.p., Snell, S.A (1999). The human resource architecture: Towards a theory of human capital allocation and development. Academy of Management Journal, 45:215-233.

Macduffie, J.P. (1995). Human Resource Bundles and Manufacturing Performance: Organizational Logic and Flexible. Industrial and Labor Relations Review, 48(2), 197-221.

Mahoney, J. T. (1995). The management of resources and the resource of management. Journal of business research, 33(2), 91-101.

Malik, O. R., \& Kotabe, M. (2009). Dynamic capabilities, government policies, and performance in firms from emerging economies: Evidence from India and Pakistan. Journal of Management Studies, 46(3): 421-450.

Mendenhall, M. Black, J. Jensen, R. and Gregersen, H. (2003). Seeing the Elephant: Human Resource Management Challenges in the Age of Globalization. Organizational Dynamics. 32 (3), 261-274.

Mellahi, K., \& Collings, W. (2010). The Barriers to effective talent management: The example of corporate elites in MNEs. Journal of World Business, 45,143-149.

Milliman, J., Von Glinow, M. A., \& Nathan, M. (1991). Organizational life cycles and strategic international human resource management in multinational companies: Implications for congruence theory. Academy of management review, 16(2), 318-339.

North, D.C. (1990). Institutions, institutional change, and economic performance. Cambridge, UK: Cambridge University Press.

Pavitt, K. (1991). Key Characteristics of the Large Innovating Firm. British Journal of Management, 2(1), 41-50. 
Peng, M.W., Wang, D.Y.L., \& Jiang, Y. (2008). An institutionbased view of international business strategy: a focus on emerging economies. Journal of International Business Studies, 39: 920-936.

Prahalad, C. K., \& Hamel, G. (1990). The core competence of the corporation. Harvard Business Review, 68(3), 79-91.

Ray, Barney \& Muhanna (2004). Capabilities, Business Processes, and Competitive Advantage: Choosing the Dependent Variable in Empirical Tests of The Resource-Based View. Strategic Management Journal, 25: 23-37.

Ricart, J.E., Enright, M.J., Ghemawat, P., Hart, S.L., \& Khanna, T. (2004). New frontiers in international strategy. Journal of International Business Studies, 35(3): 175-200.

Saá-Pérez, P. D., \& García-Falcón, J. M. (2002). A resource-based view of human resource management and organizational capabilities development. International Journal of Human Resource Management, 13(1), 123-140.

Scott, W.R. (1995). Institutions and Organizations. Thousand Oaks, CA: Sage Publications.

Shen, J. (2011). Developing the concept of socially responsible international human resource management. The International Journal of human resource management, 22(06), 1351-1363.

Singer, P. (2002). One World: The Ethics of Globalisation (Yale University Press, New Haven, CN/London, UK)

Sorge, A. (2004). Cross-national differences in human resources and organisations, chapter 5, in Harzing, A.-W. and van Ruysseveldt, J. (Eds), International Journal of Cross Cultural Management, 1(1):22-24.

Spreitzer, G.M., McCall, Jr., M.W. and Mahoney, J.D. (1997). The early identification of International Executives. Journal of Applied Psychology, 82:6-29.

Stroh, L.K. Caligiuri P.M. (1998). Increasing global competitiveness through effective people management. Journal of World Business, 33:1-16.

Thompson, L.J. (2010). The Global Moral Compass for Business Leaders. Journal of Business Ethics. 93:15-32

Tyson, S. (1997). Human resource strategy: a process for managing the contribution of HRM to organizational performance. Inter- 
national Journal of Human Resource Management, 8(3), 277290.

Tyson, S. (1997). Human resource strategy: a process for managing the contribution of HRM to organizational performance. International Journal of Human Resource Management, 8(3), 277290.

Ulrich, D., Brockbank, W., Johnson, D., \& Younger, J. (1995). Human resource competencies. The RBL Group. Available online at

http://www.hrnorge.no/wp-

con-

tent/uploads/2013/07/HumanResourceCompetenciesRisingtom eetthebusinesschallenge.pdf [Accessed on $13^{\text {th }}$ October, 2014].

Viceri, A. and Fulmer, R. (1997). Leadership by Design. Boston: Harvard Business School Press.

Vroom, V. (1993). Two decades of research on participation. Yale Management, 5,22-23

Wernerfelt, B. (1984). A resource-based view of the firm. Strategic management journal, 5(2), 171-180.

Wood, G., Mazouz, K., Yin, S., and Cheah, J.E-T. (2014). Foreign direct investment from emerging markets to Africa: The HRM context.

Wright, P. M., McMahan, G. C., \& McWilliams, A. (1994). Human resources and sustained competitive advantage: a resourcebased perspective. International journal of human resource management, 5(2), 301-326. 